\title{
Fra Vicko Kapitanović i istraživanje hrvatske filozofske baštine
}

\author{
DARIo ŠKARICA* - IVAN MACUT** \\ • https://doi.org/10.31823/d.28.3.7• \\ UDK: 1(091)*27-789.32(497.5) • Pregledni članak \\ Primljeno: 26. prosinca 2019. • Prihvaćeno: 8. rujna 2020.
}

\section{${ }^{*}$ Izv. prof. dr. sc.}

Dario Škarica, Institut za filozofiju, Zagreb, Ulica grada Vukovara 54, 10000 Zagreb, Hrvatska

- Filozofski fakultet u Splitu, Sveučilište u Splitu, Poljička cesta 35, 21000 Split, Hrvatska, dskarica@ffst.hr

** Doc. ddr. sc. Ivan Macut, Katolički bogoslovni fakultet Sveučilišta u Splitu, Zrinsko-frankopanska 19,

21000 Split, Hrvatska, ivanmacut@libero.it
Sažetak: Hrvatska filozofska baština trajni je istraživački zadatak. Nisu mnogobrojni koji su se tom zadatku posvetili. Jedan od onih koji je prepoznao važnost teme bio je fra Vicko Kapitanović, franjevac i povjesničar. Važnost njegova istraživačkoga rada na tom području dolazi do izražaja u tome što je temeljito istražio, popisao, opisao i na svjetlo dana iznio brojne latinske filozofske rukopisne tekstove iz 18. i 19. stoljeća koji se čuvaju u samostanima Franjevačke provincije Presvetoga Otkupitelja u Makarskoj, Šibeniku, Visovcu, Živogošću, Splitu, Sinju, Omišu, Zaostrogu, Sumartinu i Karinu. Uz to, izlažući o pojedinim filozofskim rukopisima, Kapitanović redovito opisuje i povijest dotičnih samostanskih filozofskih škola, navodeći iscrpno, koliko je to bilo moguće, i podatke o franjevcima filozofima koji su na tim učilištima predavali. $U$ ovom je radu prikazan taj vrijedan Kapitanovićev doprinos istraživanju povijesti hrvatske filozofije.

Ključne riječi: fra Vicko Kapitanović, povijest hrvatske filozofije, Franjevačka provincija Presvetoga Otkupitelja, povijest školstva, filozofski rukopisi, skotizam.

\section{Uvod}

$\mathrm{Na}$ jednom mjestu o važnosti i poteškoćama istraživanja hrvatske filozofske baštine napisali smo ovako: »Istraživati hrvatsku filozofsku baštinu iznimno je izazovan, ali također i zahtjevan zadatak. To se ponajprije očituje u problemu izvora, literature i metodologije. $\ll^{1} \mathrm{Uz}$ te poteškoće i sta-

${ }^{1}$ Usp. I. MACUT, Hrvatska filozofija od obnove Zagrebačkog sveučilišta 1874. do osnutka Nezavisne Države Hrvatske 1941., Split, 2018., 19. 
novite preprjeke, Ljerka Schiffler o razdoblju 18. stoljeća piše da su to stoljeće i filozofska djelatnost Hrvata u njemu neravnomjerno istraženi, a onda posljedično i neadekvatno vrjednovani. ${ }^{2} \mathrm{U}$ svojim istraživanjima filozofskih učilišta i filozofskih rukopisa u samostanskim bibliotekama Franjevačke provincije Presvetog Otkupitelja fra Vicko Kapitanović (1944. - 2015.) ponajviše se bavio upravo tim, 18. stoljećem.

U ovom radu $^{3}$ želimo upozoriti na Kapitanovićev doprinos u okviru istraživanja filozofskih učilišta Franjevačke provincije Presvetog Otkupitelja i filozofskih rukopisa koji se čuvaju u raznim samostanskim knjižnicama te Provincije, kojoj je Kapitanović i sam kao redovnik i franjevac pripadao.

Jedna od poteškoća pri istraživanju filozofskoga života, poučavanja i produkcije unutar redovničkih zajednica na području nastanjenu Hrvatima sastoji se u mnogobrojnosti pokrajinskih i biskupijskih filozofskih učilišta, u njihovu relativno neznatnu, ponajviše pokrajinskom utjecaju, ponekad i u njihovu kratkotrajnu postojanju. Uz to, istaknimo i činjenicu da su mnogobrojna (ne samo) filozofska djela ostala u rukopisima te su redom pisana na latinskom jeziku, kojim se, i u spomenutom razdoblju i danas, služe malobrojni ljudi. Ipak, treba naglasiti da je već dosta toga istraženo. Sjetimo se, primjerice, kad je o slavonskim franjevcima riječ, o njihovim filozofskim učilištima i rukopisima, vrijednih istraživanja fra Franje Emanuela Hoška i Zlatka Posavca. ${ }^{4}$ Ili, kad je o hercegovačkim i bosanskim franjevcima riječ, podsjetimo na jednako tako vrijedna istraživanja fra Serafina Hrkaća. ${ }^{5}$

\footnotetext{
${ }^{2}$ Usp. LJ. SCHIFFLER, Iz hrvatske filozofske baštine 18. stoljeća: disertacija Josipa Zanchija, u: Prilozi za istraživanje hrvatske filozofske baštine 32(2006.)1-2(63-64), 189-206., ovdje 189.

${ }^{3}$ Ovaj je rad tekst predavanja održana na Međunarodnom znanstvenom simpoziju »Život i djelo fra Vicka Kapitanovića «. Simpozij je održan na Katoličkom bogoslovnom fakultetu Sveučilišta u Splitu dana 6. prosinca 2018. godine.

${ }^{4}$ Vidi primjerice F. E. HOŠKO, Slavonska franjevačka učilišta, Zagreb, 2011.; F. E. HOŠKO, Filozofsko učilište u Baji u XVIII. stoljeću (1725.-1783.), u: Godišnjak za znanstvena istraživanja Zavoda za kulturu vojvođanskih Hrvata 2(2010.), 225-250.; F. E. HOŠKO, Franjevci u Slavoniji: vjerska, prosvjetna i kulturna misija, u: V. KUSIN, B. ŠULC, S. ANDRIĆ (ur.), Slavonija, Baranja i Srijem. Vrela europske civilizacije, I, Zagreb, 2009., 315-334.; F. E. HOŠKO, Školstvo i crkveni redovi, u: I. GOLUB (ur.), Hrvatska i Europa: kultura, znanost i umjetnost, sv. 3: Barok i prosvjetiteljstvo (XVII.XVIII. stoljeće), Zagreb, 2003., 187-202.; Z. POSAVAC, Filozofski rukopisi u franjevačkim samostanima Slavonije, Zagreb, 1993.

${ }^{5}$ Vidi primjerice u: S. HRKAĆ, Filozofijski rukopisi na latinskom jeziku franjevačke biblioteke u Kraljevoj Sutjesci, u: Prilozi za istraživanje hrvatske filozofske baštine 4(1978.)1-2(7-8), 257-288.; S. HRKAĆ, Fojnički filozofijski rukopisi na latinskom jeziku, u: Prilozi za istraživanje hrvatske filozofske baštine 8(1982.)1-2(15-16), 125-166.; S. HRKAĆ, Cursus triennalis universae philosophiae Aristotelico-Scotisticae, auctore p. Antonio Xderich, u: Prilozi za istraživanje hrvatske filozofske baštine 15(1989.)1-2(29-30), 193-199.; S. HRKAĆ, Introductio in universam Aristotelis philosophiam
} 
No, kad je riječ o području Franjevačke provincije Presvetog Otkupitelja, o kodikološkom opisu i istraživanju pojedinih latinskih filozofskih rukopisa, kao i istraživanju povijesnih činjenica vezanih uz pojedina filozofska samostanska učilišta te franjevce koji su na njima predavali, nezaobilazno i istaknuto mjesto pripada fra Vicku Kapitanoviću. ${ }^{6}$ Kad se uzme u obzir i činjenica da u brojnim samostanima još uvijek biblioteke i arhivi nisu sređeni po pravilima struke, onda Kapitanovićev stručan, detaljan i marljiv istraživački rad na tom području još i više dobiva na važnosti.

Uz bavljenje crkvenom poviješću, koja je bila Kapitanovićeva uža specijalnost, područje na kojem je objavio najveći broj radova, postoji i desetak radova objavljenih na hrvatskom jeziku, jest istraživanje hrvatske filozofske baštine. Svoje istraživanje te iznimno važne teme Kapitanović je usredotočio na filozofske škole i filozofske rukopise iz 18. i 19. stoljeća u samostanskim knjižnicama Franjevačke provincije Presvetoga Otkupitelja. U svojem istraživanju obuhvatio je sljedeće samostane, samostanske knjižnice i područne filozofske škole: Makarska, Šibenik, Visovac, Živogošće, Gospa od Zdravlja u Splitu, Sinj, Omiš, Zaostrog, Sumartin i Karin.

Dubrovčanina Blaža Šimića, u: Prilozi za istraživanje hrvatske filozofske baštine 16(1990.)1-2(3132), 211-217.; S. HRKAĆ, Manuskript fra Petra Karapandžića 'Logica', u: Mostariensia (1994.)1, 50-55.; S. HRKAĆ, Filozofijski manuskripti na latinskom jeziku u Bosni Srebrenoj, Mostar, 1998.; S. HRKAĆ, Izlaganje o univerzalijama u djelu Antuna Žderića 'Enchyridion in universam AristotelicoScoticam philosophiam', Mostar, 1998.; S. HRKAĆ, Uspostava sustavnog školstva u Bosni Srebrenoj (Bosna Argentina) u 18. st., u: Zbornik radova XI., Mostar, 1998., 253-275.; S. HRKAĆ, Fra Franjo Marušić, Logica minor a. 1741. scripta, Mostar, 1999.; S. HRKAĆ, Metaphysica p. Antonii Xderich, u: Prilozi za istraživanje hrvatske filozofske baštine 27(2001.)1-2(53-54), 231-285.; S. HRKAĆ, Summulae sive logica parva p. Antonii Xderich, u: Prilozi za istraživanje hrvatske filozofske baštine 29(2003.)1-2(57-58), 303-386.; S. HRKAĆ, Tractatus brevis in libros Aristotelis 'De mirabili mundo coelique machina' p. Antonii Xderich a Vinkovacz, u: Prilozi za istraživanje hrvatske filozofske baštine 30(2004.) 1-2(59-60), 175-235.

${ }^{6}$ Uz Kapitanovića, poznavanju školstva i filozofskih rukopisa u Franjevačkoj provinciji Presvetog Otkupitelja svojim su istraživanjem znatno pridonijeli i fra Jure Brkan te fra Petar Bezina. Vidi primjerice u: J. BRKAN, L'organizzazione scolastica della Provincia del SS.mo Redentore in Dalmazia nel Settecento (pars disertationis), Romae, 1982.; J. BRKAN, Školovanje svećeničko-redovničkih kandidata Provincije presvetog Otkupitelja u XVIII. stoljeću, u: Kačić (1984.)16, 7-58.; J. BRKAN, Povijesni pregled djelovanja Franjevačke visoke bogoslovije u Makarskoj, u: ISTI (ur.), Franjevačka visoka bogoslovija Makarska: 250. obljetnica osnivanja i rada 1736.-1986., Makarska, 1989., 83-99.; J. BRKAN, Bogoslovna učilišta provincije presvetog Otkupitelja u Hrvatskoj, u: Historijski zbornik 43(1990.) 1, 149-166.; J. BRKAN, Visoko školstvo na Visovcu, u: Visovački zbornik, Visovac, 1997. 209-227.; J. BRKAN, Ivan Duns Škot i Franjevačka visoka bogoslovija u Makarskoj, u: Hrvatski škotizam XX. stoljeća, Zbornik radova znanstvenog skupa Zagreb-Katuni-Split 27. - 29. V. 2008., Città del Vaticano, 2011., 201-234.; P. BEZINA, Srednje školstvo u Franjevačkoj provinciji Presvetog Otkupitelja (1735-1920), Split, 1989.; P. BEZINA, Rukopisna baština franjevaca Provincije Presvetoga Otkupitelja, Zagreb, 1993. 
Može se primijetiti da je Kapitanović o toj problematici iz hrvatske filozofske baštine radove počeo objavljivati 1992. godine te su gotovo svi ti radovi objavljeni u časopisu Prilozi za istraživanje hrvatske filozofske baštine (izuzev onoga objavljenoga u Antonianumu 1992.7 i onoga o Visovcu objavljenoga u Visovačkom zborniku 1997. godine). Zadnji, deseti rad iz toga područja objavio je Kapitanović 2011. godine.

U ovom se radu ne ćemo zadržavati na svim objavljenim radovima detaljno, nego ćemo naglasiti najvažnija Kapitanovićeva dostignuća, zapažanja i korekcije pogrješnih zaključaka do kojih su došli njegovi prethodnici u istraživanju iste rukopisne građe. Potrebno je naglasiti i to da je fra Vicko Kapitanović kao član Franjevačke provincije Presvetoga Otkupitelja i provincijski arhivist, stručnjak iz crkvene povijesti i izvrstan poznavatelj latinskoga jezika imao pristup svim samostanskim bibliotekama i arhivima u Provinciji. Ne samo da je imao pristup nego je imao i znanje o tome gdje i što tražiti, znanje tim važnije što je često bila riječ o nesređenoj i nepopisanoj rukopisnoj građi pa bi neupućenoj osobi bilo vrlo teško bilo što korisno pronaći i upotrijebiti.

Napomenimo da zasad nema znanstvenih ni stručnih radova u cijelosti posvećenih Kapitanovićevu istraživanju filozofske rukopisne baštine Franjevačke provincije Presvetog Otkupitelja. Dijelom je toj temi posvećen članak Ljerke Schiffler iz 2007. godine. ${ }^{8}$ Dijelom joj je posvećen i članak Veronike Reljac iz 2011. godine. ${ }^{9}$ Dijelom joj je posvećen i In memoriam fra Vicku Kapitanoviću u Prilozima za istraživanje hrvatske filozofske baštine. ${ }^{10}$ Iscrpnu bibliografiju fra Vicka Kapitanovića (s popisom izabranih radova o njemu) objavio je Marko Trogrlić, 2016. godine u Kačiću. ${ }^{11} \mathrm{U}$

\footnotetext{
${ }^{7}$ Usp. V. KAPITANOVIĆ, Testi scotistici d'insegnamento filosofico-teologico nella provincia del Santissimo Redentore in Croazia nei secoli XVII e XVIII, u: Antonianum 67(1992.)2-3, 240-304. U ovom radu Kapitanović obrađuje ukupno 53 filozofska rukopisa ( $\mathrm{k}$ tomu i 18 teoloških rukopisa). Iste filozofske rukopise, s izuzetkom onih triju iz samostana u Karinu (kodeksi VIII, X i XIV), uvrstit će Kapitanović u svoja kasnija, znatno opsežnija istraživanja objavljivana u Prilozima za istraživanje hrvatske filozofske baštine od 1992. do 2011. godine i u Visovačkom zborniku 1997. godine.

${ }^{8}$ Usp. LJ. SCHIFFLER, Doprinosi Vicka Kapitanovića hrvatskoj kulturnoj povijesti, u: Filozofska istraživanja 107(2007.)27(3), 699-702.

${ }^{9}$ Usp. V. RELJAC, Doprinos Hrvatskog franjevačkog biografskog leksikona upoznavanju hrvatske filozofske baštine, u: Prilozi za istraživanje hrvatske filozofske baštine 37(2011.)1-2(73-74), 75-92.

${ }^{10}$ Usp. D. ŠKARICA, In memoriam: fra Vicko Kapitanović (1944-2015), u: Prilozi za istraživanje hrvatske filozofske baštine 41(2015.)2(82), 539-541.

${ }^{11}$ Usp. M. TROGRLIĆ, Bibliografija prof. dr. fra Vicka Kapitanovića (1944.-2015.), u: Kačić (2016.)48-49, 155-188.
} 
Splitu je 6. prosinca 2018. godine na Katoličkom bogoslovnom fakultetu održan međunarodni znanstveni skup Život i djelo fra Vicka Kapitanovića. ${ }^{12}$

\section{Filozofsko učilište i franjevačka biblioteka u Makarskoj}

Franjevačkoj knjižnici u Makarskoj posvećena su tri Kapitanovićeva rada. Povijest knjižnice izložio je opširno 1989. godine u radu Franjevačka knjižnica u Makarskoj, objavljenom u zborniku Franjevačka visoka bogoslovija u Makarskoj: 250. obljetnica osnivanja i rada 1736.-1986., koji su uredili fra Jure Brkan i fra Hrvatin Gabrijel Jurišić (Makarska, 1989., Kapitanovićev prilog otisnut je na str. 108-173.). Filozofske rukopise pisane na latinskom jeziku što ih knjižnica čuva iscrpno je opisao 1992. godine u članku Latinski filozofski rukopisi u Franjevačkoj knjižnici u Makarskoj (Prilozi za istraživanje hrvatske filozofske baštine, 18, 1-2 (35-36), str. 201-245.). Cjelovit prikaz rukopisnoga i knjižnoga fonda, ne samo filozofskoga nego i teološkoga, prirodoslovnoga itd., Kapitanović je dao 1993. godine u knjizi Rukopisna i knjižna baština Franjevačke visoke bogoslovije u Makarskoj (Makarska, 1993.). ${ }^{13}$ Pritom se, jasno, kad je o objavljenim djelima riječ, ograničio na inkunabule, knjige iz 16. st. i hrvatske rijetke knjige.

Nije čudno što je Kapitanović toliko istraživačkoga truda posvetio upravo franjevačkoj samostanskoj knjižnici u Makarskoj: »Franjevačka knjižnica u Makarskoj najveća je knjižnica u Provinciji Presv. Otkupitelja i na području između Splita i Dubrovnika. ${ }^{14}$ Početke knjižnice treba vezati uz sam osnutak makarskoga franjevačkoga samostana u 15 . st. ${ }^{15} \mathrm{U}$ samostanu je 1708 . godine osnovano filozofsko učilište, a bogoslovno 1736. godine, čime se i rukopisni fond knjižnice i te kako povećavao zbog sve većih potreba obaju učilišta, tj. studenata i profesora koji su na njima predavali i studirali. ${ }^{16}$

Kapitanović je izradio prvi stručni katalog franjevačke knjižnice u Makarskoj, s iscrpnim popisom i kodikološkim opisom pojedinih rukopisa, prema u svijetu uvri-

\footnotetext{
${ }^{12}$ Skup su organizirali Katolički bogoslovni fakultet Sveučilišta u Splitu, Odsjek za povijest Filozofskoga fakulteta Sveučilišta u Splitu, Pontificia Università Gregoriana (Rim), Pontificia Università Antonianum (Rim) i Sveučilište u Mostaru.

${ }^{13}$ Među prikazima te Kapitanovićeve knjige istaknimo ovdje sljedeći: J. KOLANOVIĆ, Vicko Kapitanović, Rukopisna i knjižna baština Franjevačke visoke bogoslovije u Makarskoj. Niz: Spomenička baština Franjevačke provincije Presvetog Otkupitelja. Makarska 1993, 367 str., u: Arhivski vjesnik 37(1994.), 323-324.

${ }^{14}$ V. KAPITANOVIĆ, Latinski filozofski rukopisi u Franjevačkoj knjižnici u Makarskoj, u: Prilozi za istraživanje hrvatske filozofske baštine 18(1992.)1-2(35-36), 201-246., ovdje 201.

${ }^{15}$ Usp. isto.

${ }^{16}$ Usp. isto.
} 
ježenim pravilima katalogizacije rukopisne građe. No važnost tih Kapitanovićevih radova, ranije navedenih (iz 1989., 1992. i 1993. godine), posvećenih franjevačkoj knjižnici u Makarskoj, sastoji se i u tome što eksplicitno definiraju Kapitanovićev pristup sveukupnom istraživanju rukopisne filozofske baštine Franjevačke provincije Presvetog Otkupitelja: prvo, iscrpan kodikološki opis pojedinoga rukopisnoga djela, s naznačenim pojedinim njegovim svescima i glavnim dijelovima; drugo, upute na varijante, odnosno prerade spomenutoga rukopisa i na njemu slične rukopise u navedenoj ili u nekoj drugoj knjižnici Franjevačke provincije Presvetog Otkupitelja kako bi se u konačnici utvrdili mogući utjecaji među pojedinim rukopisima unutar knjižnica Provincije, kao i izvan Provincije, u Hrvatskoj ili u inozemstvu (posebno u Italiji i u Mađarskoj); treće, utvrđivanje autorstva (tamo gdje autor nije naznačen); četvrto, upućivanje na rezultate prethodnih istraživanja spomenutoga rukopisa; peto, podatci o knjižnici, njezinu fondu i povijesti; šesto, podatci o učilištu uz koje je knjižnica vezana, o njegovu statusu (pokrajinskom ili generalnom), o njegovoj povijesti i o profesorima i studentima koji su na njemu predavali odnosno studirali; sedmo, upućivanje na literaturu o navedenoj knjižnici i učilištu. ${ }^{17}$ Tih se načela i ciljeva Kapitanović drži u svim svojim radovima o rukopisnoj filozofskoj baštini Franjevačke provincije Presvetog Otkupitelja.

\section{Filozofsko učilište i franjevačka biblioteka u Šibeniku}

Uz samostan u Makarskoj, posebno je za Franjevačku provinciju Presvetoga Otkupitelja važan samostan u Šibeniku. Naime na provincijskom kapitulu Bosne Srebrene u Velikoj 1699. godine osnovan je u samostanu sv. Lovre u Šibeniku Licej, odnosno Arhigimnazij, kako se još zvao. ${ }^{18}$ Godine 1725. u Šibeniku je umjesto dotadašnjega provincijskog bogoslovnog učilišta osnovano generalno bogoslovno učilište drugog stupnja, uz koje je djelovalo i filozofsko učilište. ${ }^{19}$ Godine 1735. to šibensko opće teološko učilište drugoga stupnja podignuto je na razinu općega teološkoga učilišta prvoga stupnja te će u tom statusu djelovati sve do austrijske reforme školstva u Dalmaciji 1825 . godine. ${ }^{20} \mathrm{~S}$ tim u vezi Kapitanović naglašava: »Iako je filozofsko učilište u Šibeniku imalo pokrajinsko značenje, upravo njegovo susjedstvo s Općim teološkim učilištem i zajednička knjižnica

\footnotetext{
${ }^{17}$ Usp. isto, 202-203. Usp. također V. KAPITANOVIĆ, Rukopisna i knjižna baština Franjevačke visoke bogoslovije u Makarskoj, Makarska, 1993., 17-18.

${ }^{18}$ Usp. V. KAPITANOVIĆ, Rukopisni priručnici Franjevačkog filozofskog učilišta u Šibeniku (16991825), u: Prilozi za istraživanje hrvatske filozofske baštine 20(1994.)1-2(39-40), 157-199., ovdje 157.

${ }^{19}$ Usp. isto, 158-159.

${ }^{20}$ Usp. isto, 159.
} 
davale su mu prednost pred ostalim učilištima i u znanstvenom pogledu podizale njegov ugled. ${ }^{21}$

Uz kratke povijesne crtice o nastanku učilišta, Kapitanović ukratko izlaže i o nastanku biblioteke. U početku samostan nije imao biblioteku, nego su knjige čuvane u gvardijanatu. Bilo ih je svega 316 svezaka, zajedno s rukopisima. Današnja biblioteka osnovana je 1772. godine, a u njoj »se sačuvalo dosta rukopisnih priručnika od kojih su neke pisali profesori tog učilišta, a drugi su se upotrebljavali kao priručnici na tom učilištu $\ll^{22}$. Kapitanović nije samo popisao filozofske rukopise u toj biblioteci nego donosi i vrlo vrijedne podatke o porijeklu pojedinih rukopisa, tj. odakle je koji rukopis došao ili kako je nastao. Tako primjerice ističe najstariji filozofski priručnik što ga knjižnica čuva, rkp. 126 [Institutiones philosophicae], koji potječe iz 1646. godine s učilišta u Forliju, nepoznata autora. ${ }^{23}$ Nadalje, spominje i pet rukopisa iz Napuljskog Kraljevstva koji su prispjeli u Franjevačku provinciju Presvetog Otkupitelja, a knjižnica u Šibeniku posjeduje dva (prvo, rkp. 131, Summularum tractatus, Philosophia naturalis seu Physica, predavanja Bonaventure Abatina, izlagana 1678. godine na učilištu sv. Didaka u Napulju, kojima je dodana kvestija pod naslovom Quid requiritur ad universale logicum, et an detur Mateja Moschelle da S. Stefano, kasnijega generalnoga ministra franjevačkoga reda, poznatoga i kao Matheus a Messana, i drugo, rkp. 121, koji potječe s filozofskoga učilišta u Cosenzi, a autor mu je Leo a Morano: In universam Aristotelis philosophiam ad mentem theologorum omnium principis Ioannis Duns Scoti, 1704.). ${ }^{24}$ Uz te rukopise, Kapitanović spominje i one koji su u Šibenik preneseni iz Rima, među njima i rukopis poznatoga irskoga franjevca Francisa Portera (1632. - 1702.) pod naslovom Comentarii in octo libros physicorum Aristotelis iz 1668. godine (rkp. 138). ${ }^{25}$ Ističe posebno i dva rukopisa iz Genove. ${ }^{26}$

Kada je riječ o hrvatskim autorima filozofskih rukopisa u franjevačkoj knjižnici u Šibeniku, Kapitanović primjećuje sljedeće:

»Profesori filozofije na šibenskom učilištu ostali su potpuno u sjeni profesora teološkog učilišta. To je i razumljivo stoga što je teološko učilište bilo na najvišoj razini učilišta franjevačkog reda pa su se i profesori različitih učilišta natjecali da dobiju katedru teologije u Šibeniku. Profeso-

\footnotetext{
${ }^{21}$ Usp. isto.

${ }^{22}$ Usp. isto, 160-161.

${ }^{23}$ Usp. isto, 161.

${ }^{24}$ Usp. isto, 162-163.

${ }^{25}$ Usp. isto, 163-164.

${ }^{26}$ Usp. isto, 164-165.
} 
ri prvih triju desetljeća nisu ostavili nikakvih filozofskih djela ili su ona zagubljena. $\ll{ }^{27}$

Prema Kapitanoviću, prvi su radovi vezani uz franjevačko filozofsko učilište u Šibeniku potekli od fra Ivana Turića. ${ }^{28}$ Pritom Kapitanović ističe posebno Turićevu Logiku, dovršenu 1733. godine, koja se čuva u knjižnici franjevačkoga samostana u Zaostrogu: »Zaostroški tekst bez sumnje je prvi Turićev istinski filozofski tekst koji je, čini se, izvršio daljnji utjecaj u dalmatinskom dijelu Bosne srebrene i kasnijoj Provinciji Presvetog Otkupitelja, utjecaj koji će daljnja istraživanja trebati osvijetliti i vrednovati njegovu filozofsku misao. $\ll^{29}$

Znatan je utjecaj izvršio i rukopis Disputationes in Aristotelis Metaphysicam, prerađen nekoliko puta, kojemu je autor vjerojatno fra Jeronim Filipović. ${ }^{30}$ Kapitanovićev je zaključak o Filipovićevu utjecaju sljedeći:

$\gg$ Filipovićevi rukopisi prerađeni u kasnijem razdoblju potvrđuju pretpostavku da su se pojedini priručnici zadržali duže vremena u upotrebi kao pomagala na filozofskim učilištima Provincije Presvetog Otkupitelja. Najvjerojatnije je to bilo zbog toga što svaki lektor nije izrađivao vlastiti priručnik. (...) Istina god. 1766. Bujas je upravo u Zaostrogu izradio I. svezak svog priručnika Philosophia, no Filipovićeve Disputationes ostale su i dalje cijenjene, kako pokazuje Mrnjavčev prijepis izrađen upravo na zaostroškom učilištu. $\ll^{31}$

Kapitanović je izradio i popis (utvrđenih) predavača filozofije na šibenskom učilištu. ${ }^{32}$

U više navrata Kapitanović ispravlja ranije, posebno Božitkovićeve zaključke u vezi s pojedinim filozofskim rukopisima iz franjevačke knjižnice u Šibeniku - primjerice, Božitkovićeve zaključke o fra Ivanu Turiću ili o fra Bonaventuri Kriliću itd. ${ }^{33}$ Ozbiljnost Kapitanovićeva pristupa očituju i njegova razmatranja o drugim franjevcima vezanima uz šibensko filozofsko učilište, primjerice o fra Bartolomeju Ribaroviću ili o fra Marijanu Lekušiću. ${ }^{34}$ Pritom Kapitanovićevu znanstvenu oz-

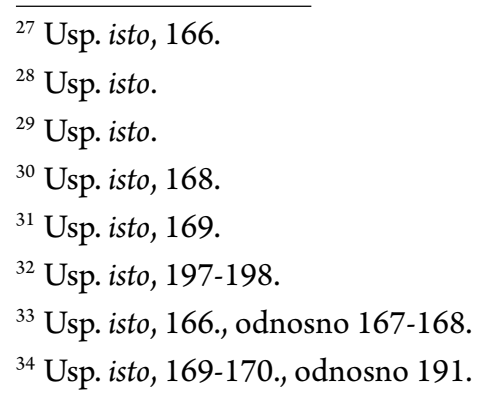


biljnost krasi i odmjerenost suda o vlastitim istraživačkim postignućima, upravo skromnost, samozatajnost, posebno jasna usporedimo li je s uloženim istraživačkim trudom. Možda i najjasnije, kad je riječ o istraživanju filozofskih rukopisa u šibenskoj franjevačkoj knjižnici, te dvije osobine, ozbiljnost i odmjerenost, dolaze do izražaja u zaključnim rečenicama Kapitanovićeve rasprave o spomenutim rukopisima, neposredno prije njihova kodikološkoga opisa:

$\gg$ Uz iznesene napomene kodikološki opis rukopisa, koji slijedi, trebao bi barem donekle olakšati napore budućim istraživačima povijesti hrvatske filozofije u razlučivanju i vrednovanju filozofske misli sadržane u tim rukopisima. Zbog višestrukog autorstva djela u nekim rukopisima i zbog još uvijek neriješenog pitanja autorstva većeg broja rukopisa odustao sam od bilo kakve razdiobe $u$ kodikološkom opisu te slijedim redoslijed kataloške signature. Nadam se, ipak, da će i tako skroman prikaz odškrinuti vrata budućim istraživanjima povijesti filozofske misli u Hrvatskoj. ${ }^{35}$

\section{Franjevačka biblioteka na Visovcu}

Istražujući biblioteku franjevačkoga samostana na Visovcu, Kapitanović zaključuje kako su filozofski i teološki priručnici koji se u njoj nalaze u biti ostavština preminulih franjevaca te su imali školsku svrhu, a često su njihovi autori nepoznati, dok samo ponekad imamo zabilježena imena prepisivača i prerađivača. ${ }^{36}$ Najstariji je priručnik iz filozofije u toj knjižnici Disputationes logicae (rkp. 21), a napisao ga je fra Filip Vodanović, najvjerojatnije, smatra Kapitanović, slušajući predavanja nekoga milanskoga profesora u vrijeme Kandijskoga rata 1646 . godine. ${ }^{37} \mathrm{Uz}$ taj rukopis, od domaćih priručnika biblioteka čuva anoniman rukopis pod naslovom Disputationes in octo libros physicorum Aristotelis (rkp. 18), koji je sličan nekim rukopisima u samostanima u Karinu, Omišu, Makarskoj i Splitu. Kapitanović ističe kako je taj rukopis s Visovca skoro istovjetan onomu koji se nalazi u samostanu u Karinu. ${ }^{38} \mathrm{Uz}$ to Kapitanović posebno ističe i Disputationes in Aristotelis Metaphisicam (rkp. $19 \mathrm{i}$ rkp. 26), što su u biti preradbe rukopisa fra Jeronima Filipovića iz samostanske bi-

\footnotetext{
${ }^{35}$ Usp. isto, 170.

${ }^{36}$ Usp. V. KAPITANOVIĆ, Visovački školski priručnici XVI.-XVIII. st., u: Š. SAMAC (ur.), Visovački zbornik, Zbornik radova simpozija u prigodi 550-te obljetnice franjevačke nazočnosti na Visovcu 1445.-1995., Visovac, 1997., 309-328., ovdje 310.

${ }^{37}$ Usp. isto, 310.

${ }^{38}$ Usp. V. KAPITANOVIĆ, Testi scotistici d'insegnamento filosofico-teologico nella provincia del Santissimo Redentore in Croazia nei secoli XVII e XVIII, 268-269. Usp. također V. KAPITANOVIĆ, Visovački školski priručnici XVI.-XVIII. st., 310.
} 
blioteke sv. Lovre u Šibeniku. ${ }^{39}$ Od ostalih autora filozofskih rukopisa u biblioteci na Visovcu Kapitanović ističe fra Josipa Glunčevića (njegova predavanja, držana na šibenskom učilištu, zabilježena 1779. godine, sadržaj su rkp. 20) i fra Anđela Kačića Miošića (rkp. 24, Cursus philosophicus, Udine, 1795.). ${ }^{40}$

\section{Filozofsko učilište i franjevačka biblioteka u Živogošću}

Franjevačko filozofsko učilište u Živogošću djelovalo je možda još od 1640. godine. ${ }^{41}$ Sigurno je međutim da ono djeluje od 1748 . do 1773 . godine. ${ }^{42}$ Koliko je poznato, na živogoškom je filozofskom učilištu predavalo ukupno sedam profesora, koje Kapitanović navodi uz živogoške profesore na gramatičkoj školi i na studiju moralnoga bogoslovlja. ${ }^{43}$ Kapitanović je, koliko mu je bilo moguće, opisao i filozofsku djelatnost svakoga od navedenih profesora na filozofskom učilištu u Živogošću. ${ }^{44} \mathrm{O}$ važnosti filozofskoga učilišta u Živogošću Kapitanović argumentirano zaključuje da je ono bilo manje cijenjeno od učilišta u Šibeniku i Zaostrogu. ${ }^{45}$

Što se tiče filozofskih rukopisa sačuvanih u knjižnici franjevačkoga samostana u Živogošću, ukupno njih sedam, uglavnom su iz logike i fizike i, zapravo, nisu bili izrađeni za potrebe samoga filozofskoga učilišta u Živogošću, nego su u knjižnicu dospjeli kao ostavština franjevaca preminulih u živogoškom franjevačkom samostanu. ${ }^{46}$

\section{Filozofsko učilište i franjevačka biblioteka u samostanu Gospe od Zdravlja u Splitu}

Provincijsko filozofsko učilište na Dobrom u Splitu osnovano je 1748. godine, a razlog osnivanja vrlo vjerojatno bio je velik priljev studenata. ${ }^{47} \mathrm{Uz}$ kraće ili dulje

\footnotetext{
${ }^{39}$ Usp. isto, 311.

${ }^{40}$ Usp. isto, 312-313.

${ }^{41}$ Usp. V. KAPITANOVIĆ, Filozofsko učilište u Živogošću (1748-1772) i rukopisni priručnici u franjevačkoj knjižnici, u: Prilozi za istraživanje hrvatske filozofske baštine 23(1997.)1-2(45-46), 203217., ovdje 203.

${ }^{42}$ Usp. isto, 203-204.

${ }^{43}$ Usp. isto, 205-207.

${ }^{44}$ Usp. isto, 205-208.

${ }^{45}$ Usp. isto, 209.

${ }^{46}$ Usp. isto, 214.

${ }^{47}$ Usp. V. KAPITANOVIĆ, Filozofsko učilište i rukopisi u Franjevačkom samostanu Gospe od Zdravlja u Splitu 1748-1826, u: Prilozi za istraživanje hrvatske filozofske baštine 27(2001.)1-2(5354), 287-320., ovdje 287-288.
} 
prekide učilište djeluje do 1826 . godine. ${ }^{48}$ Kapitanović uspijeva utvrditi ukupno dvanaestoricu lektora filozofije na splitskom filozofskom učilištu, pri čemu iscrpno obavještava, koliko mu je bilo dostupno i poznato, o izborima lektora na tom pokrajinskom filozofskom učilištu, kao i o nedaćama i poteškoćama na koje su nailazili. ${ }^{49}$ Kada su austrijske vlasti provele opsežnu odgojnu i obrazovnu reformu na crkvenom području, to je ujedno označavalo i kraj maloga provincijskoga učilišta. ${ }^{50}$ Naime te su se mjere »odnosile na primanje kandidata u crkvene redove, na dob redovničkog oblačenja i zavjetovanja te na razinu obrazovanja. (...) Austrijsko dvorsko povjerenstvo za studij odredilo je da osnutkom javnog teološkog zavoda u Zadru trebaju prestati s radom samostanska učilišta u Dalmaciji jer ne zadovoljavaju teološkoj razini i nemaju dovoljno studenata, a studenti su upućeni u Zadar na filozofski studij. $\ll{ }^{51}$ Zanimljiva je Kapitanovićeva primjedba uz tu odluku austrijskoga dvorskoga povjerenstva:

»Takva državna odluka postala je zapravo novi izazov. Provincija Presvetog Otkupitelja okupila je međutim snage, školovala profesore na stranim sveučilištima i izborila dopuštenje za vlastito filozofsko-bogoslovno učilište. To je mogla učiniti samo sa sviješću o vrijednosti njezinih prethodnih ulaganja u školovanje, kulturu i znanost (...). U svakom slučaju, iz upotrebe će nestati brojnih raznolikih filozofskih priručnika. U svim krajevima carevine studirat će se uglavnom prema istim priručnicima, ako je to napredak, a filozofsko školovanje skraćeno je od tri na dvije godine. ${ }^{52}$

Kapitanović izvještava odvojeno, u zasebnim odsječcima, najprije o tiskanim filozofskim priručnicima, a potom i o rukopisima što se čuvaju u knjižnici franjevačkoga samostana Gospe od Zdravlja u Splitu. Ističe pritom da je posrijedi mala biblioteka, koja nije imala znanstvenu, nego obrazovnu svrhu:

>Zbog toga u njoj i nema djela velikih filozofa, a slabo su zastupljeni čak i veliki crkveni pisci, pa čak i predvodnik franjevačke škole Duns Škot. Ali zato ima više primjeraka filozofskih školskih priručnika. Oni su ponajviše tiskani u XVIII. i početkom XIX. stoljeća, a to znači da su ih uglavnom pribavljali franjevci koji su živjeli u vrijeme kad je u Splitu djelovalo filozofsko učilište. $\ll^{53}$

\footnotetext{
${ }^{48}$ Usp. isto, 287-289.

${ }^{49}$ Usp. isto, 293-302.

${ }^{50}$ Usp. isto, 301-302.

${ }^{51}$ Usp. isto, 301 i 302.

${ }^{52}$ Usp. isto, 302.

${ }^{53}$ Usp. isto, 303.
} 
Kad je riječ o tiskanim filozofskim priručnicima koji se čuvaju u knjižnici franjevačkoga samostana Gospe od Zdravlja u Splitu, Kapitanović na uvjerljiv način argumentira u prilog pretpostavci da su u samostan dospjeli uglavnom vezano uz rad filozofskoga učilišta. ${ }^{54}$ Pritom su to uglavnom priručnici stranih autora, objavljeni u inozemstvu. ${ }^{55}$ Što se pak tiče filozofskih rukopisa sačuvanih u istoj knjižnici, ukupno ih je šest, ${ }^{56}$ a Kapitanovića su u istraživačkom smislu posebno motivirala prva dva. U vezi s prvim, Kapitanović argumentira da mu je autor fra Jeronim Filipović, ${ }^{57}$ dok u vezi s drugim, nedvojbeno utvrdivši da mu je autor također fra Jeronim Filipović, upozorava na njegovu sličnost s Kačićevim Elementa peripatetica (Venecija, 1752.). Razmatranje zaključuje pretpostavkom da su Filipovićev rukopis i Kačićeva Elementa sastavljeni prema nekom zajedničkom uzoru (vjerojatno nekom opsežnijem filozofskom djelu toga doba). ${ }^{58}$

U cjelini, o splitskom franjevačkom filozofskom učilištu Kapitanović zaključuje: »Sve u svemu, usprkos pojedinim kriznim vremenima, splitsko je filozofsko učilište, može se slobodno reći, ispunilo zadaću koja mu je bila namijenjena, pružiti doličnu filozofsku naobrazbu svojim studentima. $\ll^{59}$

\section{Filozofsko učilište i franjevačka biblioteka u samostanu u Sinju}

Godine 1724. uprava Franjevačke provincije Bosne Srebrene na čelu s provincijalom fra Augustinom iz Tuzle donijela je odluku kojom su se u Provinciji, među ostalim, osnovala dva nova filozofska učilišta, i to u Makarskoj i u Sinju. ${ }^{60}$ U desetogodišnjem djelovanju sinjskoga filozofskoga učilišta u okviru Franjevačke provincije Bosne Srebrene (dakle do 1735. godine) filozofiju su predavali: Bonaventura Buljan, Petar Filipović te Andrija Stančić. ${ }^{61}$ Od 1735. godine do austrijske reforme školstva, tj. do 1826. godine (dakle u okviru Franjevačke provincije Presvetog Otkupitelja, odnosno Franjevačke provincije sv. Kaja, pape i mučenika, kako se Provincija zvala do 1743.) u Sinju su predavali sljedeći lektori filozofije: Marko Ćorić, Petar Bruner, Jeronim Filipović, Franjo Marketinović, Ivan Križanović, Bartol Ri-

\footnotetext{
${ }^{54}$ Usp. isto, 303-306.

${ }^{55}$ Usp. isto.

${ }^{56}$ Usp. isto, 306-317.

${ }^{57}$ Usp. isto, 306-307.

${ }^{58}$ Usp. isto, 307-312.

${ }^{59}$ Usp. isto, 319.

${ }^{60}$ Usp. V. KAPITANOVIĆ, Franjevačko pokrajinsko filozofsko učilište i rukopisi u Sinju do Austrijske reforme školstva, u: Prilozi za istraživanje hrvatske filozofske baštine 33(2007.)1-2(65-66), 89124., ovdje 97.

${ }^{61}$ Usp. isto, 96-99.
} 
barević, Ante Orlandić, Ivan Kardum, Franjo Puharić, Bonaventura Bilušić, Franjo Vučković, Dominik (Penović) Medvidović, Franjo Poljak, Karlo Vladić, Paškal Jurić, Ivan Živanović, Dominik Medo, Franjo Dragičević, Josip Marijan Glunčević, Lovro Kulišić, Ante Paić i Toma Mimica. ${ }^{62}$ Nabrojivši prema dostupnim provincijskim izvorima lektore filozofije, Kapitanović iznosi i podatke o njihovu životu i djelu, onoliko koliko je uspio utvrditi iz dostupnih izvora. ${ }^{63}$

Knjižnica franjevačkoga samostana u Sinju sadrži tek osam filozofskih rukopisa. ${ }^{64}$ Među njima posebno su važni rukopisi VII/2, V/3 i X/1. Prvi (rkp. VII/2), nepoznata autora, pisan je u Kanjiži u Mađarskoj u 17. st. ${ }^{65}$ Drugi (rkp. V/3), autora Petra Lipovca, pisan je također u Mađarskoj, u Baji, u 18. st. ${ }^{66}$ Treći (rkp. X/1), autora Andrije Stojčevića, pisan je u Budimu 1750. godine. ${ }^{67}$ Ta tri rukopisa svjedoče o ondašnjim vezama dalmatinskih franjevaca s franjevačkim filozofskim učilištima u Mađarskoj. ${ }^{68} \mathrm{~K}$ tomu, uz franjevačke samostanske knjižnice u Šibeniku, Visovcu i Omišu, sinjska je franjevačka samostanska knjižnica važna i istraživačima filozofskoga i teološkoga opusa jednoga od najistaknutijih franjevaca Provincije Presvetog Otkupitelja u 18. st., fra Jeronima Filipovića, jer je u njoj sačuvan ne samo filozofski rukopis ovisan o predlošku Filipovićevih predavanja (rkp. VII/3) nego i nekoliko njegovih teoloških rukopisa. ${ }^{69}$

\section{Filozofsko učilište i franjevačka biblioteka u samostanu u Omišu}

Filozofsko učilište u Omišu djelovalo je povremeno, uglavnom »u razdobljima kada se svi franjevački studenti nisu mogli smjestiti na već postojeća, više ili manje trajna učilišta $\ll^{70}$. Prema fra Petru Bezini učilište je djelovalo od rujna 1748. godine. ${ }^{71}$ Kapitanović međutim ističe da u povijesnim vrelima nema uporišta za tu tvrdnju. ${ }^{72}$ Prema

\footnotetext{
${ }^{62}$ Usp. isto, 97-106.

${ }^{63}$ Usp. isto, 96-99., 107-112.

${ }^{64}$ Usp. isto, 112-123.

${ }^{65}$ Usp. isto, 113-115.

${ }^{66}$ Usp. isto, 116-117.

${ }^{67}$ Usp. isto, 121-123.

${ }^{68}$ Usp. isto, 113-115., 116-117. i 121-124.

${ }^{69}$ Usp. isto, 120-121. i 124.

${ }^{70}$ Usp. V. KAPITANOVIĆ, Franjevačko filozofsko učilište u Omišu i latinski rukopisni priručnici do austrijske obnove školstva (1755-1827), u: Prilozi za istraživanje hrvatske filozofske baštine 35(2009.)1-2(69-70), 301-340., ovdje 303.

${ }^{71}$ Usp. isto.

${ }^{72}$ Usp. isto.
} 
Kapitanoviću, filozofsko je učilište u Omišu ustanovljeno 1755. godine. ${ }^{73}$ Prvim je lektorom filozofije u Omišu imenovan fra Jure Sabljić. ${ }^{74}$ Kad je Sabljić dovršio trogodišnji tečaj filozofije, postao je naslovni lektor teolog. ${ }^{75}$ Kapitanovićev je zaključak da s tim Sabljićevim napredovanjem studij filozofije u Omišu privremeno prestaje $\mathrm{s}$ radom, da bi, kako svjedoče povijesna vrela, 1767. godine novi lektor filozofije postao fra Bonaventura Bilas. ${ }^{76}$ Nakon tri godine (1770.) Bilas je postao lektor teologije, a vrela ne spominju nikoga kao novoga lektora filozofije, pa je moguće da je učilište privremeno prestalo $s$ radom. ${ }^{77}$ Godine 1779 . dolazi do ponovne uspostave učilišta u nekim samostanima u kojima je nastava prestala. ${ }^{78}$ Tako je u omiški samostan, uz učitelja gramatike i lektora moralke, imenovan i lektor filozofije, fra Jeronim Loze, koji je 1785. godine postao provincijal. ${ }^{79}$ Godine 1788. filozofsko učilište u Omišu ponovno je obnovljeno, a za lektora filozofije izabran je fra Paškal Mrnjavac, kojega je 1792. godine zamijenio fra Paškal Ajduk. ${ }^{80}$ Godine 1801. lektor je filozofije u Omišu fra Franjo Ravlić, koji je 1804. godine promaknut u lektora teologije. ${ }^{81}$ Nakon njega još su lektori filozofije u Omišu bili fra Jure Režić (1808.), fra Franjo Vežić (1816. i 1819.), fra Ante Lerota (1820. - 1822.) i fra Marko Šumelj $(1823 .-1827 \text {. godine })^{82}$.

O franjevačkom filozofskom učilištu u Omišu Kapitanović zaključuje:

$\gg$ Nakon pomno analiziranih podataka i kritički odvagnute njihove vrijednosti može se doći do zaključka kako je omiški franjevački samostan služio zapravo kao neka vrsta dopunskoga pokrajinskog učilišta u prilikama kada ostala filozofska učilišta zbog različitih razloga, prvenstveno zbog prehrane i smještaja studenata, nisu mogla udovoljiti potrebama školovanja mladih franjevaca. ${ }^{83}$

Što se tiče filozofskih rukopisa u biblioteci omiškoga franjevačkoga samostana, ukupno 21 rukopis, Kapitanović drži da su u knjižnicu dospjeli kao ostavština fra-

\footnotetext{
${ }^{73}$ Usp. isto, 304.

${ }^{74}$ Usp. isto, 306.

${ }^{75}$ Usp. isto.

${ }^{76}$ Usp. isto, 307.

${ }^{77}$ Usp. isto, 308.

${ }^{78}$ Usp. isto.

${ }^{79}$ Usp. isto, 308-309.

${ }^{80}$ Usp. isto, 310-311.

${ }^{81}$ Usp. isto, 311-312.

${ }^{82}$ Usp. isto, 303-316.

${ }^{83}$ Usp. isto, 338.
} 
njevaca koji su u samostanu preminuli. ${ }^{84}$ Najveći broj tih rukopisa pripada autorima koji su djelovali izvan omiškoga filozofskoga učilišta. ${ }^{85}$ Tematski gledano, rukopisi su vezani uz klasičan franjevački trogodišnji studij filozofije, koji je uključivao logiku, fiziku i metafiziku. ${ }^{86}$ Kapitanovićevim riječima:

$\gg$ Filozofski rukopisi u knjižnicu prispjeli su pretežno s drugih učilišta, kao ostavštine franjevaca koji su iz njih studirali, ili možda ih čak prepisivali. (... ) Premda je nemoguće ustvrditi da se neki od navedenih rukopisa predavao i na omiškom filozofskom učilištu, uvid u te školske tekstove odaje sustav kakav je bio na franjevačkim provincijskim učilištima, a to je više-manje vrijedilo i za učilište u Omišu, koje je, čini se, davalo studentima temeljitu filozofsku naobrazbu. $\ll^{87}$

\section{Filozofsko učilište i franjevačka biblioteka u samostanu u Zaostrogu}

Franjevačko filozofsko učilište u Zaostrogu djelovalo je spočetka unutar Franjevačke provincije Bosne Srebrene. ${ }^{88}$ Isprava o njegovu osnutku čini se da nije sačuvana. Obično se godinom početka njegova rada uzima $1726 .{ }^{89}$ Diobom Franjevačke provincije Bosne Srebrene 1735. godine zaostroško učilište nastavlja svoje djelovanje u okviru novonastale Franjevačke provincije sv. Kaja, pape i mučenika (danas Franjevačka provincija Presvetog Otkupitelja). ${ }^{90}$ Uz kraće ili i malo dulje prekide učilište je djelovalo do 1821 . godine. ${ }^{11}$ Zaostroško je učilište bilo pokrajinsko učilište, dakle u rangu biskupskoga sjemeništa. ${ }^{92}$

Kapitanović je identificirao ukupno dvadeset i dvojicu lektora filozofije u Zaostrogu. ${ }^{93}$ Dio zaostroških lektora filozofije svoje je studije završio u domovini (poput fra Andrije Kačića Miošića, u Osijeku), a dio u inozemstvu (uglavnom u Italiji, u

\footnotetext{
${ }^{84}$ Usp. isto.

${ }^{85}$ Usp. isto, 317-318.

${ }^{86}$ Usp. isto, 338.

${ }^{87}$ Usp. isto.

${ }^{88}$ Usp. V. KAPITANOVIĆ, Franjevačko pokrajinsko filozofsko učilište u Zaostrogu i rukopisni priručnici u XVIII. stoljeću, u: Prilozi za istraživanje hrvatske filozofske baštine 36(2010.)1-2(71-72), 129-168., ovdje 130.

${ }^{89}$ Usp. isto, 131.

${ }^{90}$ Usp. isto, 132.

${ }^{91}$ Usp. isto, 143.

${ }^{92}$ Usp. isto, 130-132.

${ }^{93}$ Usp. isto, 130-148.
} 
Bologni, Veneciji, Firenci, Perugi, Mantovi)..${ }^{94}$ Brojni od njih, nakon Zaostroga, predavali su i na generalnom učilištu u Šibeniku, postigavši tamo i jubilaciju, naslov ravan onom lector emeritus na državnim sveučilištima. ${ }^{95}$ Neki su bili izabrani i za definitore, odnosno provincijale Franjevačke provincije Presvetog Otkupitelja. ${ }^{96} \mathrm{Da}$ pače, fra Ante Perić imenovan je generalnim definitorom franjevačkoga reda. ${ }^{97} \mathrm{Fra}$ Mihovil Dragičević imenovan je provincijalom Albanske franjevačke provincije. ${ }^{98}$ Može se dakle zaključiti da je Zaostroško učilište uživalo znatan ugled u Provinciji, ali i stanovit ugled izvan nje. ${ }^{99}$

Uz filozofsko učilište u Zaostrogu Kapitanović veže sljedeća četiri rukopisa: Franjo Marušić, Disputationes philosophicae; ${ }^{100}$ Pavao Bujas, Philosophia ad mentem doctoris subtilis Ioannis Duns Scoti; ${ }^{101}$ Josip Franić, Disputationes philosophicae ${ }^{102}$ i Jeronim Loze, Cursus philosophicus iuxta mentem subtilissimi ac venerabilis doctoris Ioannis Duns Scoti omnium theologorum principis. ${ }^{103}$

Knjižnica zaostroškoga samostana, što se filozofskih djela tiče, uz dvije inkunabule (Questiones super quattuor libris Sententiarum metaphisicae de anima et quodlibetis abbreviatae et ordinatae per Johanem de Colonia [Duns Scotum], Venecija, 1472. i Johanes de Monte, Summularium Parisiensis Petri Hispani logicae expositio, Venecija, 1550.) čuva i znatan broj (filozofskih) rukopisa, dobrim dijelom nerazvrstanih, tako da je Kapitanović detaljno opisao samo sljedećih deset: 1. Ivan Kačić Peko, In universam philosophiam isagoges; 2. De logica; 3. Lucas Narentinus [Luka Šimunović/Vladimirović], Cursus philosophicus; 4. Ivan Ante Turić, Logica Magna; 5. Mihovil Gulin (?), Logicae cursus; 6. Disputationes in universam Ar(istote)lis Logicam;

\footnotetext{
${ }^{94}$ Usp. isto, 166.

${ }^{95}$ Usp. isto.

${ }^{96}$ Usp. isto, 167.

${ }^{97}$ Usp. isto, 166-167.

${ }^{98}$ Usp. isto, 167.

${ }^{99}$ Usp. isto, 166-168.

${ }^{100}$ Rukopis je detaljno opisan u: V. KAPITANOVIĆ, Rukopisna i knjižna baština Franjevačke visoke bogoslovije u Makarskoj, 81-83., br. 15.

${ }^{101}$ Rukopis je detaljno opisan u: isto, 61-63., br. 3. Usp. također V. KAPITANOVIĆ, Rukopisni priručnici franjevačkog filozofskog učilišta u Šibeniku, 176-177.

${ }^{102}$ Rukopis je detaljno opisan u: V. KAPITANOVIĆ, Rukopisna i knjižna baština Franjevačke visoke bogoslovije u Makarskoj, 73-75., br. 13.1-2.

${ }^{103}$ Rukopis je detaljno opisan u: V. KAPITANOVIĆ, Rukopisna i knjižna baština Franjevačke visoke bogoslovije u Makarskoj, 75-76., br. 13.3. Usp. također V. KAPITANOVIĆ, Franjevačko filozofsko učilište u Omišu i latinski rukopisni priručnici do austrijske obnove školstva (1755-1827), 326330.
} 
7. Domenico Ricciardi, Phylosophia naturalis, pars I; 8. [Ivan Turić ?], In Octo physicorum libros Aristotelis Stagiritae; 9. Conclusiones physicae; 10. Secunda philosophiae pars sive Metaphysica. ${ }^{104}$

\section{Filozofsko učilište i franjevačka biblioteka u samostanu u Sumartinu}

Franjevački samostan u Sumartinu vrlo kratko bio je i filozofsko učilište. ${ }^{105}$ Naime 1800. godine na prijedlog fra Andrije Dorotića provincijal fra Lovro Lovrić osnovao je novo učilište u Sumartinu. ${ }^{106}$ Kapitanović vjeruje da je katedru u Sumartinu dobio Mihovil Franković, koji je bio i Dorotićev prijatelj. ${ }^{107}$ Kada je Dorotić 1806. godine prestao biti provincijal, to se provincijsko učilište ugasilo. ${ }^{108}$ Kapitanović opisuje tri sumartinska filozofska rukopisa: Phisycorum libri (kodeks 12 i kodeks 16), Physica (kodeks 10) i Exaratio universae philosophiae (kodeks 8 i kodeks 9). ${ }^{109}$ Physicorum libri pripisuje fra Andriji Staničiću. ${ }^{110}$ Što se tiče ostalih triju rukopisa (kodeksi 8-10: Physica i Exaratio universae philosophiae), skupa s Barbarićem i Dadićem, Kapitanović odbacuje tezu koju je zagovarao fra Ivan Glibotić da im je autor fra Andrija Kačić Miošić, ali pritom, nasuprot Barbariću i Dadiću, iznosi mnoge argumente koji barem donekle dovode u sumnju njihovo pripisivanje tih rukopisa fra Andriji Dorotiću, ${ }^{111}$ ispričavajući se pritom zbog možda prenaglašene akribije, koju ujedno i opravdava:

$\gg$ Neka mi se oprosti moja upornost na upozoravanju na sitnice koje autorstvo mogu činiti upitnim, ali samo otklanjanjem svih upitnika može se doći do neoborive postavke (...). Ne smije se međutim izgubiti iz vida

${ }^{104}$ Usp. V. KAPITANOVIĆ, Franjevačko pokrajinsko filozofsko učilište u Zaostrogu i rukopisni priručnici u XVIII. stoljeću, 149-165.

${ }^{105}$ Usp. V. KAPITANOVIĆ, Filozofski rukopisi u franjevačkom samostanu u Sumartinu i njihovi autori, u: Prilozi za istraživanje hrvatske filozofske baštine 37(2011.)1-2(73-74), 133-148., ovdje 134-135.

106 Usp. isto, 134.

${ }_{107}$ Usp. isto, 134-135.

${ }^{108}$ Usp. isto. Za provincijala je Dorotić izabran 1803. godine. [Usp. Vicko Kapitanović, Fra Andrija Dorotić (1761.-1837.), reformator, političar i dobrotvor, Split, 2016., 55.].

${ }^{109}$ Usp. isto, 135-140.

${ }^{110}$ Usp. isto, 140-141.

${ }^{111}$ Usp. isto, 134-140. Usp. također I. GLIBOTIĆ, Filozofski rukopisi fra Andrije Kačića Miošića, u: Kačić (1973.)5, 165-166. Usp. također D. BARBARIĆ, O Kačićevim filozofskim rukopisima, u: Prilozi za istraživanje hrvatske filozofske baštine 4(1978.) 1-2(7-8), 251-255. Usp. također Ž. DADIĆ, Prilog poznavanju prirodnofilozofijskih stavova u srednjoj Dalmaciji u 18. stoljeću, u: Prilozi za istraživanje hrvatske filozofske baštine 8(1982.)1-2(15-16), 167-178., ovdje 167., D. BARBARIĆ, Filozofija Andrije Dorotića, Zagreb, 1987. 
koliko je u dokazivanju autentičnosti autorstva u često okrnjenim rukopisima, beznaznaka naslova i autora, potrebno biti oprezan i suzdržljiv. ${ }^{112}$

\section{Zaključak}

Doprinos fra Vicka Kapitanovića istraživanju hrvatske filozofske baštine vezan je u prvom redu uz filozofske rukopise pohranjene u knjižnicama Franjevačke provincije Presvetog Otkupitelja. U nizu svojih radova objavljenih od 1992. do 2011., uglavnom u Prilozima za istraživanje hrvatske filozofske baštine, Kapitanović je izvijestio o rukopisima iz samostanskih knjižnica u Makarskoj, Šibeniku, Visovcu, Živogošću, Splitu, Sinju, Omišu, Zaostrogu, Sumartinu i Karinu. Sam je definirao svoj pristup još 1992. godine u sljedećih sedam načela: prvo, iscrpan kodikološki opis pojedinoga rukopisnoga djela; drugo, upute na inačice, prijepise i prerade navedenoga rukopisa i na njemu slične rukopise u istoj ili u nekoj drugoj knjižnici Franjevačke provincije Presvetog Otkupitelja kako bi se utvrdili mogući utjecaji među pojedinim rukopisima unutar knjižnica Provincije, ali i izvan Provincije, u Hrvatskoj ili u inozemstvu (posebno u Italiji i u Mađarskoj); treće, utvrđivanje autorstva; četvrto, upućivanje na rezultate prethodnih istraživanja spomenutoga rukopisa; peto, podatci o knjižnici, njezinu fondu i povijesti; šesto, podatci o učilištu uz koje je knjižnica bila vezana, o njegovu statusu (pokrajinskom ili generalnom), o njegovoj povijesti i o profesorima i studentima koji su na njemu predavali odnosno studirali; sedmo, upućivanje na literaturu o navedenoj knjižnici i učilištu. Tih se načela Kapitanović držao dosljedno u svim njegovim spomenutim radovima.

Kapitanovićevo istraživanje filozofske rukopisne baštine Franjevačke provincije Presvetog Otkupitelja odlikuje se širinom pristupa, strpljivom i preciznom argumentacijom, izrazitim smislom za detalj, visokom razinom stručnosti i uzornom znanstvenom akribijom. K tomu, u rijetkim polemički intoniranim odlomcima Kapitanović se drukčijim stavovima i interpretacijama suprotstavljao uvijek argumentirano i odmjereno.

U cjelini, Kapitanovićev doprinos istraživanju rukopisne filozofske baštine Franjevačke provincije Presvetog Otkupitelja možemo ocijeniti iznimno vrijednim i poticajnim.

${ }^{112}$ Usp. V. KAPITANOVIĆ, Filozofski rukopisi u franjevačkom samostanu u Sumartinu i njihovi autori, 141. i 142. 


\title{
FR. VICKO KAPITANOVIĆ AND THE RESEARCH OF THE CROATIAN PHILOSOPHICAL HERITAGE
}

\author{
Dario ŠKARICA* - Ivan MACUT**
}

Summary: The Croatian philosophical heritage is an ongoing research task. There are not many who have dedicated themselves to this task. One of those who recognized the importance of the topic was Fr. Vicko Kapitanović, a Franciscan and historian. The importance of his research work in this area is expressed in the fact that he thoroughly researched, listed, described and brought to light numerous Latin philosophical manuscripts from the 18th and 19th centuries that are kept in the monasteries of the Franciscan Province of the Most Holy Redeemer in Makarska, Šibenik, Visovac, Živogošce, Split, Sinj, Omiš, Zaostrog, Sumartin and Karin. In addition, in presenting individual philosophical manuscripts, Kapitanovic regularly describes the history of the monastic philosophical schools in question, stating in detail, as far as possible, the data on the Franciscan philosophers who taught at these colleges. This paper presents Kapitanovićs valuable contribution to the research of the history of Croatian philosophy.

Keywords: Fr. Vicko Kapitanović, history of Croatian philosophy, Franciscan Province of the Most Holy Redeemer, history of education, philosophical manuscripts, Scotism.

\footnotetext{
*Assoc. Prof. Dario Škarica, Ph. D., Institute of Philosophy, Zagreb, Ulica grada Vukovara 54, 10000 Zagreb, Croatia - Faculty of Humanities and Social Sciences, University of Split, Poljička cesta 35, 21000 Split, Croatia, dskarica@ffst.hr

** Asst. Prof. Ivan Macut, Ph. DD., Catholic Faculty of Theology, University of Split, Zrinsko-frankopanska 19, 21000 Split, Croatia, ivanmacut@libero.it
} 